University of South Carolina

Scholar Commons

$5-2010$

\title{
Transnational Integration Regimes as Development Programs
}

Laszlo Bruszt

European University Institute, laszlo.bruszt@eui.eu

Gerald A. McDermott

University of South Carolina, gerald.mcdermott@moore.sc.edu

Follow this and additional works at: https://scholarcommons.sc.edu/inter_facpub

Part of the International Business Commons

\section{Publication Info}

Preprint version 2010.

(c) 2010 by Laszlo Bruszt and Gerald A. McDermott

Do Not Cite Without Permission.

This Article is brought to you by the Sonoco International Business Department, The at Scholar Commons. It has been accepted for inclusion in Faculty Publications by an authorized administrator of Scholar Commons. For more information, please contact digres@mailbox.sc.edu. 


\title{
Transnational Integration Regimes as Development Programs \\ Laszlo Bruszt \\ Professor \\ Department of Political \& Social Sciences \\ European University Institute \\ laszlo.bruszt@eui.eu
}

\author{
Gerald A. McDermott \\ Associate Professor \\ Moore School of Business \\ University of South Carolina \\ gerald.mcdermott@moore.sc.edu
}

Under R\&R; Do Not Cite Without Permission.

May 2010

\begin{abstract}
In drawing on recent advances in international and comparative political economy, this paper argues that diverging paths of institutional development among emerging market democracies are driven by the Transnational Integration Regimes (TIRs), in which a country is embedded. As development programs, TIRs differ in their effectiveness not simply in terms of their incentives and largess and more in terms of their emphasis on building institutional capacities, empowering a variety of domestic state and non-state actors via multiplex methods of assistance and monitoring, and their ability to merge monitoring and learning at both the national and supra-national levels. We develop a comparative framework to show these systematic differences through an analysis of the impact of the EU Accession Process on post-communist countries and NAFTA on Mexico, with special attention to the development of food safety regulatory institutions.
\end{abstract}

Keywords: transnational integration, development, institutions, regulation, East Europe, Mexico, food safety 


\section{Introduction}

The debate on development has recently shifted to the intersection of international and comparative political economy as research increasingly studies the ways in which external actors and regional geopolitical arrangements shape the evolution of domestic institutions in emerging democracies. (Djelic \& Sahlin-Andersson 2006, Easterly 2006, Jordana \& Levi-Faur 2005, Orenstein et al. 2008, Pevehouse 2005. Warleigh-Lack 2006) Much of this work focuses on the extent to which external incentives can insulate local political actors from various domestic interest groups. A traditional view emphasizes how arm's length incentives from political conditionality or from trade and capital liberalization force state and non-state actors to build the “right institutions.” (Mansfield \& Milner 1997, Lederman et al. 2005) Recent arguments on the crises in Latin America and the expansion of the European Union suggest that reforms stick in the most problematic cases when advanced nations impose an externally acting hierarchy on the inherently backward country. ${ }^{1}$

This paper, in contrast, argues that divergent paths of domestic institutional development are products largely of different Transnational Integration Regimes (TIRs), in which countries are embedded. Following Krasner (1982) and Ruggie (1982), we view TIRs not simply as trade pacts, aid projects, or harmonization systems, but rather as regimes that attempt to fuse social purpose and power to integrate developing countries into a transnational institutional arrangement that induces domestic institutional upgrading. In acting as development programs, TIRs differ in the ways they translate their goals and different types of power into integration

\footnotetext{
${ }^{1}$ To the extent that policy anchoring, external conditionality and related penalties are defined with such precision as to make non-compliance nearly impossible, then hierarchical power, akin to the traditional notion of international hegemony, appears to be the key solution for change. One can see this in how Amsden (2007) understands the imposition of international economic models and when Schimmelfennig \& Sedelmeier (2002, 2005) describe the force of EU incentives. Caballero \& Dornbusch (2002) proposed that the UN take over Argentina after its collapse in 2001and install a board of internationally known central bank governors to run economic policy. A more robust agenda can be found in Barnett (2004).
} 
mechanisms - namely the extent to which they emphasize institutional capacities, empower diverse local public and private actors, and merge monitoring and learning at both the national and supra-national levels. In this view, the development problem is less about the incentives and largess used by external actors to impose a particular policy and more about the ways in which TIRs alter or reinforce existing roles of and balance of power among the state and domestic stakeholders to partake in new collective institutional experiments.

A key weakness in much of the extant literature views ideal international mechanisms as those that circumvent domestic politics and empower an insulated change team to impose on society ideal designs. (Stark \& Bruszt 1998, McDermott 2002) In contrast, our approach builds on the concept of the experimental regulatory state, in which public and private actors experiment with policies and coalitions to form complex institutions that typify modern regulatory capitalism. (Bruszt 2002a, Cohen \& Sabel 2003, Levi-Faur 2006) In this view, institution building is impeded less by state capture per se than weaknesses on the demand and supply sides. Demand is impeded because potential beneficiaries within and outside the state lack the resources and voice in shaping existing or new institutional domains. (Jacoby 2000,2004, Pevehouse 2005) Supply is impeded because both state and non-state actors alone lack the resources, skills and knowledge needed for institutional upgrading.

TIRs differ in their abilities to alter the status quo of the demand and supply sides of domestic institutional change in the ways they translate their purpose and power into integration mechanisms. For instance, a reliance on arm's-length incentives tends to favor entrenched groups but provides little new resources or participatory channels for weaker groups (Collier and Handlin, 2005; Karl, 2008; Schneider, 2004). An emphasis on empowering a variety of often minority socio-economic groups and bureaucrats through transnational horizontal ties can 
facilitate alternative institutional experiments and create countervailing sources of power. TIRs can also strengthen the supply side not simply by emphasizing policy convergence but especially by providing material and knowledge resources to build administrative and regulative capacity at the national and subnational levels. Because conditionality is a multidimentional iterative process, TIRs also vary in their ability to adapt over time the integration mechanisms used to monitor criteria, deliver resources, and coordinate the two. (Sabel \& Zeitlin 2007)

Our aim here is to identify the ways in which TIRs translate their purpose and power into integration mechanisms that can capture their varying impact on the institution building process in emerging market democracies. We do so through a comparative analysis of the impact of EU Accession Process on post-communist countries and NAFTA on Mexico. ${ }^{2}$ This comparison helps control for geography, several starting conditions, access to markets and FDI from developed countries, and the membership of advanced countries in the TIR. Section I reveals how leading Latin American countries, including Mexico, lag behind several Central-East European countries (CEE) in terms of institutional development. In Sections II and III, we show how the experimentalist view of institution building helps one clarify the integration mechanisms and how they can vary along four dimensions of TIRs acting as development programs. In Sections IV and V, we compare NAFTA and the EU accession process in terms of these integration mechanisms and their impact on institutional development in Mexico and CEE countries, in general and via focused cases on the policy domain of food safety. We argue that the EU's integration mechanisms become particularly effective as they force candidate countries to submit themselves to iterative external evaluation, invest in administrative upgrading, and incorporate a variety of public and private actors into the institution building process. In contrast, Mexico

\footnotetext{
${ }^{2}$ This research is based on approximately 32 semi-structured interviews with relevant officials from the US, EU, Czech Republic, Romania, and Mexico as well as analysis of official reports from relevant government agencies and business associations.
} 
appears as a laggard because of the reliance on economic incentives and lack of institutionalization of learning and monitoring within the NAFTA framework. In this sense, the EU's ongoing eastern enlargement is no longer a process of institutional harmonization but rather a potentially profound innovation in international development.

\section{Regional Effects -- East Europe and Latin America Compared}

"I see no grounds for the future of Bulgaria, Hungary or Poland to be different from that of Argentina, Brazil or Chile.” Adam Przeworski (1991, p. 23)

In noting that the "East becomes South," Adam Przeworski highlighted the similarities between the liberalizing countries of Latin America and the CEE, including "states weak as organizations, political parties and other associations that are ineffectual in representing and mobilizing, economies that are monopolistic, over-protected and over-regulated, agricultures that cannot feed their own people, public bureaucracies that are overgrown, welfare services that are fragmentary and rudimentary." (Przeworski 1991, p. 24) Given the slight advantages Latin American countries generally had over their CEE counterparts in terms of wealth, their experience with markets and democratic governance, and implementing market reforms by the early 1990s (see Figure 1), one might have even thought that the South would have the upper hand. ${ }^{3}$

But available institutional indicators suggest that the East, particularly those countries participating in the EU Accession process, has surpassed the South. Figures 2a-c report the trends in key areas of institutional and regulatory quality using the World Bank governance indicators constructed by Kaufmann, Kraay, and Mastruzzi (2007). Figures 3a \& b take selected countries and plot the difference in their given score from that of average in their income group, as defined by the World Bank. This allows us to control for the effects of wealth endowments.

The data reveal two notable patterns. First, although the leading CEE countries do not

\footnotetext{
${ }^{3}$ WDI data show that while Mexico and Argentina had higher incomes per capita than the CEE5 for most of the 1990s, Brazil had much high income per capita than Bulgaria and Romania.
} 
have dramatic improvements, they do tend to outperform countries in their own income category and do not witness dramatic drops. Some of the laggards in the region, like Slovakia, Bulgaria, and Romania, are trending upwards. In contrast, Mexico declines over time and underperforms in its income category. Second, the data reveal that there is a growing divergence in governance indicators between the countries participating in EU Accession and those from the former Soviet Union, toward which the second tier Latin American countries appear trending.

Another indicator of regulatory and institutional robustness is the enforcement of rights for labor to organize, form associations, enter in collective dispute and make collective agreements. (Sunstein, 2000) Enforcement of such rights reveals the extent to which the strongest economic actors are politically constrained and weaker actors are empowered. Figure 4 presents comparative data on labor rights protection compiled by Mosley and Uno (2007). ${ }^{4}$ While there is a secular trend downward across all countries, the data suggest that enforcement of such laws are relatively strong (and close to the EU 15 averages) in the CEE countries, but are relatively weak in the Latin American countries, especially Mexico.

In sum, the data imply that there are diverging patterns of institutional development between those countries participating in the EU accession process and those in Latin America, particularly Mexico, despite similar starting points, despite more than 15 years of pursuing ostensibly market based reforms, and despite being associated in the two leading TIRs. While we do not discount the impact of local factors per se, the divergences suggest that regional integration factors are shaping these trends, an argument made increasingly by specialists on NAFTA and EU accession. (Lederman et al. 2005; Roland 2005; Sedelmeier, 2006; Studer \& Wise 2007) The key issue for development scholars is identifying the mechanisms of the TIRs

\footnotetext{
${ }^{4}$ Mosley \& Uno (2007) measure 37 potential violations of personal and collective labor rights, such as the incapacity (or unwillingness) to uphold labor's right to organize, murder of trade unionists, and state state action to prevent collective agreements.
} 
that can be broadly applied to other regions.

\section{Institution Building and the Role of TIRs}

Students of externally induced institutional change have sought to articulate the role of politicaleconomic incentives and asymmetric power often by searching for optimal terms of conditionality and their attendant enforcement mechanisms. While recent research on democratization acknowledges the importance a country's social and economic linkages with the developed world, it emphasizes how consolidation depends largely on external political leverage - the strong incentives for reforms via access or denial of key benefits from advanced countries or other members of the TIR. For instance, Levitsky \& Way (2006) distinguish the incentive structures for membership in NAFTA and the EU when explaining why Slovakia has advanced beyond Mexico. Pevehouse (2005) highlights the use of threats and reputational incentives by the MERCOSUR on Paraguay and the EU on Hungary. The Europeanization literature pushes further, arguing that sustained institutional change depends not simply on the arm's length incentives of EU Membership but rather meritocratic conditionality, in which the external actor uses clear detailed goals and builds the capacity to both assist in institution building and enforce compliance. (Schimmelfennig \& Sedelmeier 2005, Vachudova 2004) Such an emphasis on "committed conditionality" has also gained increasing credence in recent proposals for having NAFTA create the capacity to make certain resources available to Mexico contingent on meeting certain reform criteria. (Hufbauer \& Schott 2005, Pastor 2001, Studer \& Wise 2007)

While external conditionality helps focus attention on enforcement and commitment problems, its reliance on arm's length incentives and precise policy goals tends to mischaracterize the processes of institution building and integration. First, as Easterly (2006) has shown in his forceful critique of Western aid programs, the search for optimal conditionality 
often assumes that external actors have ex ante sufficient information about which types of institutional reforms are needed and why they failed and that domestic actors have the sufficient resources and knowledge to enact them. Second, the conventional use of conditionality construes commitment as binary and unidimentional, whereas the process of transnational community building is incremental, iterative and multivalent. For instance, Vachudova (2005, 2008) herself draws on the constructionist views of policy diffusion (Abdelal, Blyth \& Parsons 2010; Epstein 2008) in emphasizing the role of transnational horizontal professional ties between sub-national and non-government actors and the need for EU agencies to adapt their own programs and structures.

These two limitations are rooted in the tendency to view institutional building as a process in which governments can and should insulate powerful reform teams from particularistic interests and impose rapidly on society a well defined set of new rules and high powered economic incentives that would facilitate transactions and spur investment. (McDermott, 2002) Whether one advocates external actors utilizing greater trade incentives, policy anchoring, or hierarchical conditionality, the common ground is that the further a country is from the ideal institutional setting, the more imperative it is for external actors to defend domestic actors from themselves and limit them from infecting the optimal designs.

However, this view overlooks the burgeoning literature on experimental regulative capitalism, which dramatically changes one's understanding of the politics of the institution building process and, in turn, the role of external forces. Building on recent work in comparative economic governance and innovation systems, this literature understands modern societies as characterized not simply by a limited state enforcing a set of rules to constrain opportunism but especially by a broad constellation of state-backed institutions that enable 
public and private actors to share risk, monitor one another, and enhance knowledge diffusion. (Jordana \& Levi-Faur 2005, Hall \& Soskice 2001, Moss 2002, Pistor 2001; Piore \& Sabel 1984) Although sustained development is noted by the creation of state capacities, the state often ex ante does not have the requisite skills, knowledge, or resources, and, in turn, must coordinate with a variety of stakeholder groups who together have complementary resources and information. (Evans, 2004; McDermott 2007a,b, Rodrik 2004, Tendler 1997)

In this view, the politics of institution building is less about the insulation of the state and more about the ways in which a variety of empowered public and private actors experiment with new roles and rules to improve their abilities to monitor and learn from one another. (Bruszt 2002a, Sabel 1994) Arrested institutional development emerges from a low equilibrium trap in which state and non-state actors have neither the interest nor resources to explore new courses of experimentation. On the demand side, groups that might have an interest in new institutional capacities often lack the resources and channels to gain the sustained attention of the state. Entrenched groups maintain the status quo not only because they profit from it but also because there are no encompassing structures to facilitate horizontal ties to weaker groups, which can open new possibilities for experimentation and extend time horizons. (Schneider 2004, Tendler 1997) On the supply side, states often lack the "infrastructural capacities" (Mann, 1984) for coordinating institutional upgrading, while many non-state actors lack the resources to undertake their own initiatives. (McDermott 2007b)

But empowering a variety of relevant state and non-state actors into policy networks can improve the types of information and resources to be recombined and solidify "extended accountability." (Stark and Bruszt 1998, Ansell 2000) Reflecting pluralist traditions, state executives are constrained by a multiplicity of autonomous non-state groups competing for voice 
and participation. (Hellman 1998, Ekiert \& Hanson 2003) Reflecting the corporatist tradition, the state empowers relevant groups to undertake certain public responsibilities and also uses rules of participation to build collaborative relationships. (Streeck and Schmitter 1985)

In this view of institution building, TIRs influence the supply and demand problems, in turn the problem-solving capabilities of developing countries, in the ways they translate the fusion of social purpose and power into their integration mechanisms. First, TIRs vary in their emphasis on administrative and institutional capacity building in the target country, and in turn, the provision of resources and assistance to compensate for deficiencies at the domestic level. Resource transfer is not simply an incentive but a strategic tool in creating governance foundations at different levels of society.

Second, TIRs vary in the ways that they empower a variety of public and private actors, not simply via resources but particularly by enhancing their political and functional participation in institution building efforts. TIRs can be more or less proactive in giving credence to relevant domestic stakeholders and in facilitating cross-border horizontal professional and policy networks.

Third, TIRs vary in their own ability to coordinate and adapt as they attempt to merge monitoring and learning at both the supra-national and national levels. While a TIR attempts to accelerate compliance and learning in a certain country, the TIR itself has to build the capacity to learn why a country is diverging from ex ante defined path and determine the degree to which it must alter its own monitoring, training, and resource transfer strategies. In turn, integration is a process that potentially transforms national institutional capacities as well as the existing transnational regulatory framework itself. (Vachudova 2008)

\section{Variation Along Four Dimensions of TIRs}


As development programs, TIRs can be analyzed along four dimensions - breadth and depth, assistance, monitoring, and coordination. We now explain these dimensions and how they can vary according to differences in the aforementioned integration mechanisms. We then illustrate these differences in discussing how the EU accession process and NAFTA vary in their influence on institutional development in the CEE countries and Mexico, respectively.

Breadth refers to the different policy domains, in which the TIR requires institutional changes for member countries. This can be rather narrow, focusing on a few economic trade rules, or quite extensive, reaching into social and political domains. Depth refers to the emphasis a TIR places on building institutional capacity instead of only a policy change. While some TIRs emphasize changes to certain laws, others emphasize the need for a constellation of institutions to adequately regulate the given policy domain.

Assistance refers to the amount and type of resources, be they financial, informational, social or human resources, that the TIR offers a country to help build the capacities necessary to undertake the mission at hand. Monitoring refers to the TIR's capabilities to acquire and process two types of information - the degree to which the country is meeting the requisite institutional criteria or benchmarks and reasons why the country may or may not be reaching the expected benchmarks, be they technocratic or political.

Both assistance and monitoring can vary according to the degree to which a TIR actively promotes transnational dyadic or multiplex professional ties. Dyadic refers to a single channel of transmission between the principal and agent. Different types of information and resources can be transmitted in a dyadic linkage but virtually all communication and decision-making lies between two actors, such as two governments or a multilateral agency and the target government. The two dimensions are multiplex when a variety of public and private actors from both sides of 
the mission create ongoing professional relationships to shape capacity building in the target country. (Padgett \& Ansell 1993) For instance, an original basic agreement can be dyadic, but then the counterparts empower different governmental and non-governmental actors to engage each other for an extended period in a particular policy domain. The key structural distinction is that in a multiplex context there is no single gatekeeper in the developing country controlling resources, contacts, and information about the given policy domain.

Coordination refers to the extent to which the TIR institutionalizes the sharing of information and joint problem solving among its officials across different policy domains and especially between those who lead the assistance and monitoring mechanisms within a given policy domain. For instance, even if criteria are non-negotiable and inflexible, repeated information from assistance and monitoring about why the country is falling short in one domain can force deliberations within the TIR in several directions, such as revising the sequencing of steps within the domain, altering the type of assistance being delivered, or targeting resources toward particular groups better suited to undertake the given reform.

We argue that a TIR is more likely to induce sustained institutional development to the extent it a) emphasizes institutional capacity building, b) invests in multiplex assistance and monitoring capabilities, and c) institutionalizes coordination in such a way so as to merge monitoring and learning.

\section{Comparing EU Accession and NAFTA as Development Programs}

The differences between NAFTA and EU Accession with respect to the less developed countries were not evident in the early 1990s. Although NAFTA was created in 1994 with the US-Canada Trade Agreement as a template, it did aim to improve Mexico's political, economic and social institutions by anchoring its compliance with new trade, investment, labor, and environmental 
standards. (Studer \& Wise 2007, Duina 2007) Through the mid-1990s the EU member states did not view the integration of post-communist countries as vital nor did they envision the need for a new system to help these countries upgrade their institutions. (Vachudova 2005, Jacoby 2004) Only after observing backsliding in the East and great variation in meeting the Copenhagen criteria did the EU begin adjusting its traditional approach for harmonization toward a model focused on developing institutional capacities in a variety of policy domains.

EU Accession remains unparalleled in Breadth and Depth, as represented in the 31 chapters and 80,000 pages of the acquis which each candidate country must satisfy. Candidate countries had to make regulatory changes in a broad range of political, social, and economic domains. In doing so, they were required not only to incorporate Community legislation into national laws, but more importantly, "to implement it properly in the field, via the appropriate administrative and judicial structures set up in the Member States and respected by companies." (EU Commission 2007) ${ }^{5}$ That is, adoption of the acquis meant building up institutional capacity to regulate economic activities. (Bruszt, 2002b; Orenstein et al. 2008, Vachudova 2005) While compliance in all 31 chapters is a non-negotiable for full membership, it is often about phasing in standards and creating the institutional capacity to continue their implementation even after membership.

In contrast, NAFTA for Mexico is much narrower and shallower, even in areas where additional measures were taken. NAFTA focuses mainly on economic and trade policy domains, with some attention to the environment and labor rights, as specified in post-1994 agreements (the NAEEC and NAALC). It emphasizes making laws and standards of member countries compatible, so as to limit discrimination against foreign products and investors. (Duina 2007,

\footnotetext{
${ }^{5}$ See also 'Progress Reports and Enlargement Strategy Papers 1998-2003 of the European Commission' http://ec.europa.eu/enlargement/key documents/index archive en.htm
} 
Pastor 2001) Even in areas such as agriculture and phytosanitary regulation where there are many regulatory and product definitions, NAFTA largely refers to standards in international trade agreements, such as in the WTO, as goals for harmonization, but there is no specification about related institutional capacity. (Bredahl \& Holleran 1997) While compliance is effectively ex-post for Mexico, it can be an ongoing process. The NAFTA commission can authorize retroactive penalties, such as fines or temporary trade restrictions, for violations in trade, investment, and labor standards. Moreover, because of the economic dominance of the United States, Mexico must effectively adapt its product standards to those of US regulatory agencies to gain market entry.

Assistance in EU accession is noteworthy for its large and varied resources as well its multiplex channels of delivery. (Andonova 2004, Jacoby 2004, Vachudova 2005, Sabel \& Zeitlin 2007) Pre-accession assistance to the ten new member states from the CEE during 1990-2004 totaled about 28 Billion Euros. (EU Commission 2007) Although programs are often criticized for waste and delays, observers have noted that the amounts of aid have been relatively low when compared to typical international aid benchmarks and to EU or beneficiary country government outlays. (Mayhew 1998, pp 137-42; Heil 2000) Part of the reason appears to be the EU's use of a variety of forms of assistance, including policy networks of non-state experts for on-site training, and its emphasis on triggering domestic and international actors to invest in institution building. For instance, as technocrats in Brussels became overwhelmed with requests, the EU launched the Twinnings program that teams existing and former policymakers from the West to work with their CEE counterparts on particular areas. There were over 500 projects during 1998-2002. (EU Commission DG Enlargement 2004)This approach was coupled with the EU's emphasis on strengthening the roles of social partners in domestic policy making through 
suggested institutional models and supporting transnational professional ties between relevant NGOs. The expansion of Twinnings and the decentralization of such programs as SAPARD, which focused on upgrading agricultural firms and rural infrastructure, were also proactive attempts by the EU to build a multiplex structure of assistance that reached beyond the central government, as CEE government and non-government actors engaged in joint problem-solving with a variety of counterparts from the West. (Papadimitriou \& Phinnemore 2004, Bailey and Propris 2004)

Assistance in NAFTA is demand driven but notoriously minimal and dyadic. Although the NAFTA commission is a standing body with oversight powers, it is mainly an intergovernmental forum. According to Duina's (2007) estimates, the budget of the NAFTA for the Secretariat, NAALC and NAEEC is only $\$ 25$ million. The only focused assistance comes in the domain of US-Mexican border environmental policy and related infrastructure. Observers lament the paucity of financing available to meet Mexico's infrastructure needs. (Hufbauer \& Schott 2005, Studer \& Wise 2007) ${ }^{6}$ In turn, in addition to turning to the multilaterals for assistance, Mexico has increasingly sought direct assistance from relevant agencies in Canada and the US on an ad hoc basis, largely as part of inter-governmental discussions to resolve a particular trade problem. While cross-border multiplex ties can come from voluntary collaboration between relevant firms and NGOs it is not part of NAFTA's concerted approach, as it is in the EU.

\footnotetext{
${ }^{6}$ As part of the NAEEC side agreement, two NAFTA committees and the North American Development Bank (NADB) plan, evaluate, and study environmental infrastructure projects. While some of the 36 projects to date have made significant advances for Mexico, the overall program is criticized for its lack of depth and funding. As of 2005 , the NADB had about $\$ 450$ Million in capital for making loans up to $\$ 2$ Billion. The World Bank estimates a need for $\$ 25$ Billion in annual infusions for ten years to modernize Mexico's infrastructure. (Studer \& Wise 2007, pp 61-62, World Bank 2005)
} 
The EU Accession Process is also noteworthy for its investment into robust and varied monitoring capabilities in order to enhance meritocracy, accountability, and efficient use of funds. (Sabel \& Zeitlin 2007, Vachudova 2005) Besides evaluating whether a country was meeting the institutional criteria within a particular chapter or policy domain, EU monitoring focused on becoming iterative and reflexive as well as multiplex. Through the detailed Annual Reports on pre-accession progress and regular on-site inspections, external actors increasingly married accountability with problem solving. That is, evaluations were forward looking, emphasizing what needs to be done rather than penalizing permanently the candidate for previous deficiencies. By benchmarking a country's progress, relative to its past and its neighbors, their aim was to update and modify both detailed criteria and the mode of implementation. The key issue was not simply non-negotiable compliance but rather encouraging and shaping local solutions to generate effective institutional forms of regulatory screening and enforcement to meet EU standards even after gaining membership. In studies of compliance in domains as varied as health care, consumer protection, environmental safety, and regional development, scholars note how the detailed criteria varied according to context and sequencing was adapted to ensure that a foundation of institutional capacity was being built. (Andonova 2004, Jacoby 2004, Hughes et al 2004)

As with assistance programs, monitoring became increasingly and purposefully multiplex, as the EU sought to ground institution building in a diverse transnational network of state and nonstate actors. For each policy domain or acquis chapter, an EU unit worked with its counterpart in the candidate country to collect and process relevant information. Within each assistance program, outside consultants and NGOs file progress reports based on their visits and interactions with their counterparts. This may not be surprising, as the EU appears to have 
established the concerted multiplex approach for many years when entering a new policy domain. For instance, Tarrant and Kelemen (2007) and Sabel and Zeitlin (2007) show that in several domains the EU provides strong support for the creation and mobilization of relevant non-state organizations to act as both channels of decentralized information and coalition builders for the diffusion and coherence of new standards.

In contrast, monitoring in NAFTA is largely market based and dyadic. The NAFTA level inter-governmental working groups, including those of the side agreements, monitor the activities of member countries via annual reports to the Commission about their respective policy domains. These reports largely catalogue possible areas of dispute and trade discrimination, including grievances from private actors, with minimal attention to problem-solving and identification of root causes. (Hufbauer \& Schott 2005, Pastor 2001) As Duina (2007) notes, however, even grievance airing is limited since the procedures are cumbersome and NAFTA inter-governmental body seeks to prioritize sovereignty over forced harmonization. In turn, national governments have the main responsibilities to monitor standards and directly resolve trade violations. For Mexico, this effectively means responding directly to the demands of the Canadian and US regulators. Indeed, Green et al. (2006), argue that on agricultural issues, the countries have increasingly resorted to using the WTO committees or engaging in "strategic bilateralism," whereby top officials of the relevant Mexican and US agencies establish protocols to monitor compliance with product standards.

Although problematic at times, coordination in the EU Accession Process was increasingly robust. As suggested above, as actors attempted to improve assistance and monitoring, they increasingly shared information across functional and policy domains. Improving coordination emerged from the Commission's investment into a centralized, fully 
accessible data base for all areas and the attempts by EU actors to improve programs for resolving persistent adjustment problems. (Vachudova 2004, Jacoby 2004, Schimmelfennig, \& Sedelmeier 2005, Bailey and Propris 2004, Sabel and Zeitlin 2007) The diffusion of information from different sources and the creation of cross functional working groups have forced consultants and bureaucrats to reveal their respective actions and results and subject themselves to scrutiny from one another as well as from the candidate countries themselves, which are highly sensitive from being left behind and incorrectly compared with one another. In turn, programs like PHARE and Twinnings not only have been periodically revised but also implemented in a manner in which joint-problem solving becomes virtually indistinguishable from compliance detection. Moreover, the coordination among actors helped the EU launch new, more focused programs, such as ISPA and SAPARD, to both relieve the administrative burden within existing programs and improve specialization in different policy domains.

Because of the limited forms of assistance and monitoring and their dyadic structures, coordination is not strong in NAFTA. (Hufbauer \& Schott 2005, Studer \& Wise 2007) As exemplified in the use of strategic bilateralism, coordination largely takes place via ad hoc intergovernmental work groups, but the work groups themselves have limited horizontal ties. For instance, NAFTA's Committee on Sanitary and Phytosanitary Measures (SPS) meets just once a year, but is viewed as one of the more active NAFTA committees and working groups. Moreover, the SPS committee suspended in 2003 four working groups in such major product domains as dairy, fruits and vegetables, and fish. (Green et al. 2006) The NAALC provides for communication between national labor administrations, but this is largely ad hoc as disputes arise. But triggering occurs mainly when the domestic labor unions press their NOA to look into 
a problem on the other side of the border, which in the case of Mexico happened fourteen times

by 2001. (Human Rights Watch 2001)

Table 1 summarizes the main differences between the EU accession process and NAFTA

in terms of our four dimensions.

Table 1. Comparing the Four Dimensions of EU Accession and NAFTA

\begin{tabular}{|c|c|c|}
\hline Dimension & EU Accession & NAFTA \\
\hline \multirow[t]{2}{*}{$\begin{array}{l}\text { 1. Breadth \& } \\
\text { Depth }\end{array}$} & $\begin{array}{l}\text { Economic, Political, Institutional - } \\
\text { Wide variety of policy domains }\end{array}$ & Focus on economic and trade policies \\
\hline & $\begin{array}{l}\text { Focus on administrative capacity for } \\
\text { pre \& post-accession compliance; } \\
\text { detailed standards }\end{array}$ & $\begin{array}{l}\text { Focus on broad standards and } \\
\text { harmonization; possible ex post } \\
\text { sanctions; deference to national laws }\end{array}$ \\
\hline \multirow[t]{2}{*}{ 2. Assistance } & $\begin{array}{l}\text { Large and various resources; move } \\
\text { from pure demand driven to targeted } \\
\text { missions, focus on institutional } \\
\text { convergence. }\end{array}$ & $\begin{array}{l}\text { Limited largely to environment, weak } \\
\text { resources; ad hoc requests to } \\
\text { multilaterals and governments of US } \\
\text { and Canada. }\end{array}$ \\
\hline & $\begin{array}{l}\text { Increasingly decentralized and } \\
\text { multiplex, resulting in extended public } \\
\text { private and transnational networks. }\end{array}$ & $\begin{array}{l}\text { Increasingly dyadic b/n govts; use of } \\
\text { market and voluntary ties. }\end{array}$ \\
\hline \multirow[t]{2}{*}{$\begin{array}{l}3 . \\
\text { Monitoring }\end{array}$} & $\begin{array}{l}\text { Integrated compliance and problem- } \\
\text { solving; regular, intense scrutiny. }\end{array}$ & $\begin{array}{l}\text { Ex-post compliance; annual } \\
\text { centralized review; increase of } \\
\text { bilateral negotiations. }\end{array}$ \\
\hline & $\begin{array}{l}\text { Increasingly multiplex, resulting in } \\
\text { extended public private and } \\
\text { transnational networks. }\end{array}$ & $\begin{array}{l}\text { Mainly dyadic, with some exception } \\
\text { of environment. }\end{array}$ \\
\hline $\begin{array}{l}4 . \\
\text { Coordination }\end{array}$ & $\begin{array}{l}\text { Regular exchange of information and } \\
\text { joint-problem solving; reflexive and } \\
\text { adaptive. }\end{array}$ & $\begin{array}{l}\text { Commission administers; reliance on } \\
\text { ad hoc bilateral work groups. }\end{array}$ \\
\hline
\end{tabular}

\section{The Integration Mechanisms Shaping Domestic Institutional Change}

We now show how differences between the two sets of integration mechanisms embodied in the two TIRs shape the supply and demand sides of domestic institution building, first with a general overview and then with a focused comparison of food safety regulation. ${ }^{7}$ While the two TIRs use liberated markets to increase incentives of domestic actors to upgrade institutions, they vary

\footnotetext{
${ }^{7}$ We do not enter here in the discussion of variation in the effects of EU conditionality across countries or policy domains. Here we just stress that EU is neither a homogeneous polity, nor a regime of homogenizing: its effects might vary by policy sector and these effects are mediated by diverse domestic conditions that might differ dramatically.
} 
considerably in terms of the emphasis on capacity building, decreasing the domestic costs of adjustment, support transnational horizontal ties, and harness the initiatives and policy participation of a variety of state and non-state actors.

On the supply side, the increased use by the EU of multiplex ties, inter-unit coordination, and institutional capacity benchmarks has led monitoring to be increasingly oriented to problemsolving and relieved the EU actors from immersing themselves in local implementation details. The process in many ways begins with the National Accession Partnership reports, which are written by both EU and target country officials and detailed the progress to date in every policy domain as well as clarified the steps that the country was taking to fulfill the various objectives. The reports effectively set real time benchmarks for the candidate country that the given government and the EU would use to gauge commitment and new areas of focused assistance. (Jacoby 2004, Sabel \& Zeitlin 2007) At the EU level, inter-unit coordination becomes focused on evaluating the government's capacity to regulate a particular domain and identifying which types of non-EU actors, such as those linked to the Twinnings and PHARE programs, can most readily assist the government in improving its personnel and standards. At the country level, government agencies occupy themselves with combining the resources of relevant foreign and domestic actors to implement the given standards.

In contrast, NAFTA's focus on open trade standards and deference to national product standards leave the issues of institutional capacity building to Mexican political and economic pressures. NAFTA committees serve largely to catalogue trade grievances and to steer the relevant government officials toward avoiding retaliatory trade measures. Mexican officials then focus their attention on negotiating for increased market access for specific products, often benefiting the most powerful corporations and sectoral interest groups. (Hufbauer \& Schott 2005, 
Pastor 2001) Even when NAFTA aims to provide material assistance and coordinate activities between US and Mexican agencies, as in border environment programs, the focus is on common monitoring standards, rather than harnessing the potential capacity upgrading of government and non-government actors. (Studer and Wise 2007) Such limited roles for NAFTA decrease its influence over time. On the one hand, the Mexican government may not view a key regulatory issue as vital to reforms. For instance, although the Technical Working Group on Pesticides began in 1996 to harmonize standards, Mexico only began its active participation in 2004. On the other hand, bilateral coordination increases, but responds mainly to crisis. For instance, as we will see below, Mexico received limited ad hoc assistance from the US in meeting certain food safety standards mainly after products were banned by the US agencies. But without a focus on building regulative capacities, trade liberalization embeds domestic struggles for institutional change in a competitive market environment and constrains the room for different groups trying to push for considerations that should count in the making of the rules of the economy.

On the demand side, the EU Accession process purposively attempts to expand the variety of public and private participants in the institution building process, and NAFTA tends to narrow and conserve the status of the actors relevant for a given policy domain. NAFTA relies heavily on multilateral and bilateral standards to act as incentives for domestic actors to build their own capacities or pressure the Mexican government to offer broader institutional changes. Yet the tendency is for the most resource-rich and well-organized to voice and enact change. NAFTA offers few if any provisions to aid weaker groups and firms to either organize more effectively or develop new capabilities and practices. For instance, much of the work on manufacturing and agriculture reveals that most upgrading depends on the strategies of large firms toward suppliers and work organization. (Locke \& Romis, 2010, Gereffi \& Lee) Most 
sectors are too poor and fragmented to develop sectoral associations to fill this gap or pressure the government to provide requisite resources. In turn, domestic firms often cannot meet international standards to simply hook into international value chains, let alone invest in capabilities to participate in more value added activities. (Lederman 2005, Pastor 2001) For instance, Gallagher (2007) has shown that even in Guadalajara, which received considerable investment from high-tech MNCs, the lack of assistance programs and regulatory institutions has led to weak trade associations, minimal local sourcing, high rates of exit, and severe environmental damage. NAFTA does not have focused programs on building cross-border policy and professional networks. The closest provisions for this are in the environmental and labor side agreements. But as noted above, the evidence to date reveals that cross-border interactions depend largely on ad hoc initiatives on the part of Mexican groups.

In contrast, the integration mechanisms of the EU Accession process place strong emphasis on empowering a variety of domestic actors to participate in and benefit from the creation of new regulatory capacities and standards. First, by focusing monitoring and assistance on the process of institution building, the EU effectively linked economic reforms with political participation and helped keep domestic voice constant. By emphasizing the roles of social partners and sub-national public actors, the EU helped increase the likelihood that governments took into account a greater diversity of interests (Börzel and Risse, 2000; Vachudova, 2005). Epstein (2008) and Jacoby (2004) also have shown that in policy domains as diverse as agriculture and transportation, the introduction of new standards and regulations helped trigger the mobilization of both state and non-state actors in the institution building process that had previously been overlooked. Indeed, the EU has recently made explicit that a key lesson from problematic cases of institutional reform is the need for assistance programs to 
support more directly a variety of domestic groups demanding improved administrative and regulative capacities. (EU Commission DG-General Enlargement 2007)

Second, assistance often focuses directly on strengthening the economic and organizational capacities of weaker actors to meet new standards. As Andonova (2004) notes, the creation of "enabling institutions" initiated by the domestic government with the ISPA and SAPARD programs helped a variety of firms to incorporate international practices and participate in the market, while sub-national government and non-government actors obtained the resources and training to implement new community standards.

Third, the multiplex nature of assistance and monitoring empowered previously marginalized or weaker economic and social groups. Multiplex assistance and monitoring offered relatively weaker stakeholder groups a diverse set of resources, contacts, and information, which together strengthened their abilities to participate actively in institution building, both before and after accession. One result of this approach has been the relatively strong growth in domestic and international NGOs in CEE countries relatively to Mexico. For instance, according to the UIA data, between 1994 and 2004 Poland, Hungary, the Czech Republic and Slovakia witnessed on average a three-fold increase in the participation of its citizens in international NGOs while Mexico saw only a $23 \%$ increase. $^{8}$

Several of the assistance programs have directly targeted non-state actors and aimed at empowering sub-national actors. For instance, Buskova and Pleines (2006) show that EU assistance programs aimed at domestic NGOs have helped create powerful local allies in the upgrading of environmental regulations. Grugel (2004) and Jacoby (2008) argue that this "coalitional approach" to policy change is a concerted action on the part of the EU - directly and

\footnotetext{
${ }^{8}$ The data are normalized for population sizes. The differences in the growth rates for the absolute numbers are slightly less. The normalized growth rates for membership in Bulgaria and Romania for 1994-2004 were both around 90\%. Source: Union of International Associations, Yearbook of International Organizations, various years.
} 
coordinated with non-state actors - to build transnational and domestic alliances to diffuse standards and to reinforce the roles of different groups. The "empowered multiplexity" of the EU undermines notions that the accession process is namely a game of hierarchy. The EU relies often on vibrant horizontal ties among state and non-state actors to improve and implement standards and regulations. (Sabel \& Zeitlin 2007, Tarrant \& Kelemen 2007) Strengthening the variety of domestic "watchdogs" allows for decentralized rule enforcement and compensates for the limits to monitoring institutional consolidation from Brussels. (Tallberg 2002) Similarly, Jacoby (2004) and Andonova (2004), among others, have shown that the EU coordinates with transnational and domestic non-state actors to strengthen public-private networks within a target country and to improve all parties' abilities to learn and monitor one another.

\section{Va. The Development of Food Safety Standards and Institutions}

The foregoing discussion suggests that while the integration mechanisms of EU Accession push the institution building process in the CEE to be proactive in creating regulatory capacity and empowering a variety state and non-state actors, those of NAFTA push the process to be reactive to largely dyadic economic incentives. These differences become readily apparent in the domain of food safety, despite many similarities for the two TIRs. In both cases, the less developed countries have legacies of weak regulatory systems and highly fragmented, poorly organized agriculture sectors, but became highly dependent on exporting their food products to the more advanced countries of the respective TIRs in the 1990s. All the countries of the EU and NAFTA are also signatories of the SPS agreement of the WTO, which aims to balance the promotion of scientific standards for food safety, the right of importing countries to have more stringent standards, and the avoidance of standards becoming used as trade barriers. (Natioanl Research Council 2000; Ansell \& Vogel 2006; Gatzweiler et al. 2002) Within such a trading 
regime, the default development path confines diffusion to global buyers and MNCs requiring relatively few local suppliers to meet international standards with limited spillovers into the domestic institutions. (Gereffi \& Lee 2009) The question is how other transnational integration mechanisms help to amplify the attendant institutional changes. The combination of the EU preventive approach to food safety and its use of multiplex assistance appears to help the development of domestic state capacities as well as fortify participation of a variety of stakeholder groups and the organizational capacities of a variety of firms. In contrast, the weakening of NAFTA bodies with its initial emphasis on trade incentives has led to increased ad hoc crisis assistance by the US for relatively few Mexican actors, a lack of national regulatory and assistance infrastructure, and a political emphasis on combating standards as barriers to US market access.

\section{Food Safety for EU Accession Countries}

Following its "farm to fork" approach, the EU requires the candidate countries to undergo a complete systemic change in food safety from one focused from passive monitoring and sanctions to one focused on pro-active monitoring and prevention. The institutional requirements include detailed standards about state capacities to administer, monitor and enforce EU food safety regulations, and the ability to design and implement policies in the area of food safety. While the new institutional structures of risk management are integrated into an EU-wide network of rapid response and risk assessment agencies, their objective is to diffuse and monitor industry self-inspection practices that ensure product and process standards. Companies are required to implement $\mathrm{HACCP}$, to identify and evaluate hazards that affect product safety; to establish mechanisms for routine checking and control; to monitor performance; and to record the results of the control activities. 
For the sake of brevity, we focus here on the Czech and Romanian cases. By the end of the 1990s, EU and FAO reports noted severe problems, including the lack of relevant legislation, weak government certification and monitoring institutions, deficient border inspection posts and information systems, as well as substandard practices all along the value chains. From 1999 to their respective accession dates, the EU spent via their PHARE and SAPARD programs over 110 Mill Euros in the Czech Republic and over 200 Mill Euros in Romania on strengthening both regulatory capacities and firm capabilities in food safety. ${ }^{9}$

In both cases, beyond requirements to pass relevant legislation, the EU focused first on improving the effectiveness of government agencies - including the creation of new agencies with greater autonomy and enhancing their horizontal coordination. Through PHARE and the Twinnings programs, the Czechs and Romanians improved their technological, organizational, and human resources to be able to track the complete value chains, monitor both products and processes, expand and improve their networks of laboratories, border inspection posts, and field inspectors. Teams from the DGs also established a system of on-site inspections all along the value chain, from farms to food processing plants to border inspection posts. As they gained greater confidence in the capacities of the Czech and Romanian authorities, they focused oversight on the practices of domestic agencies, which managed inspections and support programs for firms and local infrastructure, like SAPARD. By the time of EU memberships, the majority of Czech and Romanian food safety personnel were in their regional and county inspection departments and labs and a majority had at least university degrees. (Dolezal \& Janackova 2005, EU Comission 2009)

\footnotetext{
${ }^{9}$ We draw here on several sources. The relevant EC Reports on these countries can be found at http://ec.europa.eu/agriculture/external/enlarge/publi/index en.htm . See also, Garcia-Martinez et al. (2006), Gatzweiler et al. (2002), Mishev \& Valcheva (2005), and Yakova (2005/06).
} 
Monitoring of country progress began with the required the National Plans for Agriculture and Rural Development, which led national authorities not only to jump start their abilities to identify deficiencies and track the flow of food products but also to establish benchmarks used for further EU progress reports. The European Food and Veterinary Office and DG SANCO experts used regular visits and reports to analyze the transposition of EU standards as well as the enforcement and monitoring of EU standards at the levels of the state and the food business operators. PHARE and SAPARD Reports acted as complementary controls, focusing mostly on the way assistance programs could direct resources to domestic state and non-state actors to achieve progress in meeting EU standards and ensure that domestic agencies were adequately linked into the EU-wide rapid alert system. At the same time, the EU sought to enhance domestic monitoring by requiring relevant sub-national actors and NGOs partake in regular reviews and such committees as SAPARD and the food safety coordinating commissions.

Compliance was generally inflexible for legislation and the overall soundness of the regulatory architecture. But compliance was used often to identify problems and map a plan of progress. That is, the governments negotiated transition periods for such areas as certification of laboratories, border inspection posts and exporting firms. In the Czech Republic, as late as 2002, PHARE found deficiencies in 3 border inspection posts, and immediately launched a joint program with the Czech authorities to improve practices. The EU 2009 report found Romania had resolved over 200 institutional deficiencies that had been identified in 2006, the year of membership. Deficient food processing establishments were typically given three year transition periods to invest in the adequate systems and standards. In the meantime, the food could be sold in domestic markets, given different labeling in the EU markets, and in some cases completely shut out of the EU markets for the suspension period. Such a process also compelled local 
authorities to ramp up thousands of inspections, leading to the closure of establishments - over 900 in the Czech Republic and over 250 in the meat sector alone in Romania in 2005. ${ }^{10}$

The use of assistance programs by the EU highlights the emphasis not simply on transferring resources and technical knowledge but especially on empowering a diverse set of actors and strengthening transnational ties. While PHARE focused on national institutions, much of its resources were directed to using the Twinnings program. (Bailey \& Propris 2004, Papadimitriou \& Phinnemore 2004) For instance, from 2000 to 2003, Romania established multi-year Twinnings projects with their counterparts in Germany, Italy and the Netherlands to reorganize the ministry of agriculture, implement the rapid alert system, and upgrade the national institute for biological products. PHARE also supported Czech and Romanian authorities to participate in EU wide food safety forums and coordinate reforms with neighboring countries. SAPARD and TAIEX focused on strengthening subnational state and non-state actors. For instance, in Romania SAPARD and TAIEX funded over 80 training programs of national and regional inspectors in 2005-2007 and the technical upgrading of 16 laboratories located in eight regions. SAPARD was also responsible to help national authorities establish firm level training and upgrading programs via local food safety inspection and extension offices and the relevant associations. Prior to the accession process, neither country had an upgrading model. Given the highly fragmented industry structures, with Romania being the worst case in the EU, the costs of implementing new standards and technologies were prohibitive for most firms. In 2002-03 alone, SAPARD funded over 250 projects to upgrade Czech firms and in 2005-2008 it funded over 450 upgrading projects in Romania. By 2005, $100 \%$ of dairy firms and $42 \%$ of beef processing firms in the Czech Republic had fully implemented HACCP. (Dolezal \& Janackova 2005) Although Romania lags other CEE countries, it still made significant strides. For

\footnotetext{
${ }^{10}$ The data come from Dolezal \& Janackova (2005) and ANSVSA Annual Report for 2005.
} 
instance, from 2005 to 2007, the number of beef producers meeting EU standards grew from 11 to about $400 .{ }^{11}$

The use of multiplexity extended to domestic interest groups as well. From the beginning of accession, the EC partnered with the COPA-COGEC, the EU-wide umbrella chamber for agricultural associations, to draw their CEE counterparts into an EU professional network and help them reorganize to participate in government reforms, establish new local representations, and channel services, such as SAPARD programs, to their member firms. (Bavorova et al 2005) While the PHARE program funded forums and working groups for west and east European associations, Twinnings subsidized bilateral partnerships between associations between two countries. Today, three Czech associations and one Romanian federation are active members of COPA-COGEC. ${ }^{12}$ In both countries, the associations, including those representing consumers, became major conduits in producing and distributing numerous food safety guides to food processing firms and farms and helped organize town hall meetings on the subject. (Dolezal \& Janckova 2005; EU Commission 2009)

Although the EU's efforts appear not to have spurred relatively active roles for the associations in Romania, they appear to have both strengthened the organizational capabilities and the diversity of interests in the Czech Republic. For instance, not only COPA-COGEC activities but also Twinnings partners from Austria, Germany, and Ireland helped their Czech counterparts build professional structures and access EU accession programs for their members. Moreover, these actions appear to have promoted a healthy competition of interests and an EU identity. (Yakova 2005/06) For instance, the Czech association, representing the largest farms, was an active participant in SAPARD programs and food safety policy. After 1999, three

\footnotetext{
${ }^{11}$ ANSVSA Annual Reports, 2005-2007.

${ }^{12}$ There are 14 agricultural associations in the Czech Republic and 13 in Romania.
} 
associations merged to form a stronger association of small farms. Although this association broke from the industry federation, it has found role promoting and participating in EU programs for rural development. In turn, as much as the agenda setting nature of EU accession awoke the dormant minorities, the coordinated multiplex investment into transnational, non-government networks empowered and upgraded the capacities of these Czech groups as well as a diversity of interest group representation.

\section{NAFTA, Mexico, and Food Safety}

NAFTA provided two major regulatory changes for Mexican food producers. (Duina 2007, Lederman et al. 2005) First, it phased out the antiquated form of government subsidies to producers and formally opened trade, with a 10-15 year phase out of relevant tariffs. Second, Article 722 defined a full set of international food standards, mimicking the principles of the GATT and the WTO, established a new committee on SPS matters, but kept regulatory authority largely in the hands of national actors. Economically, these changes led to a significant rise in exports of produce and animal products to the US, as well as a strong and sustained growth in rural unemployment. (Hufbauer \& Schott 2005) Institutionally, they reflect broader dimensions of integration we outlined earlier for NAFTA. The criteria are rather narrowly defined and shallow. While agricultural reforms focus on lowering trade barriers and strengthening market forces, food safety focuses on the WTO's principles of scientific standards and equivalence (the use of product standards set by the importing country), without reference to support for or priorities in building the institutional capacity in Mexico. Monitoring and assistance reside mainly at the national levels, with the SPS committee resources constrained and functioning mainly as an intergovernmental coordinating body that focuses on reducing related trade barrier disputes. 
This approach has decreased the role of multi-lateral coordination and the NAFTA bodies while increasing the role of dyadic, inter-governmental negotiations, namely between the USDA and FDA, as the regulators of the largest market, and their Mexican counterparts in SENASICA. (Green et al 2006) As mentioned above, the SPS committee met only once a year and even suspended several key working groups. Although NAFTA promoted the creation of the nonprofit Fruit and Vegetable Dispute Resolution Corporation (DRC) in 1999, its activities focus on US-Canadian commercial disputes. Indeed, as of 2009, only 23 of the almost 1300 member firms are from Mexico. Moreover, when the US suddenly issued an import alert on all Mexican cantaloupes in 2002, Mexico took the dispute to the WTO's SPS committee, not NAFTA's. Meanwhile, rather than investing in NAFTA's potential regulatory capacity, the US took greater unilateral control in defining food safety norms, exemplified in the 1997 Produce and Imported Food Safety Initiative, which not only increased the authority and resources of the USDA and FDA to monitor imported food but also, similar to the EU, placed greater emphasis on the importance of producers to use preventive practices like GAPs and GMPs. Such measures effectively shifted the role of external administrator of assistance, monitoring, and coordination onto the US. As we will now see, although this shift has led Mexico to change laws and the US to guide some institutional improvements, the differences between the two TIRs remain stark because of reliance on economic incentives and weak support for both state and non-state actors.

On the supply side, in response to the 1997 US initiative and increased suspension of import of different Mexican produce (e.g., because of microbial hazards and pestilence), the Mexicans mimicked the CEE countries in passing two sets of legislation between 1999 and 2001 that aimed to bring food safety laws, their regulation, and implementation to meet US standards. The first legislative initiative focused on combining the participation and resources of national 
and state level government agencies as well as some sectoral associations and institutes to analyze, design and implement regulatory needs and practices. The analysis revealed that as late as 2000 , less than $53 \%$ of firms in fruits and vegetables identified the need to establish a system of GAPs and GMPs, 34\% had the minimal infrastructure to implement these practices, and only $11 \%$ had adapted international practices. (Avedeno et al 2006, p. 63) But the second legislation initiative, under a new administration, diluted resources, shifted the emphasis of food safety reforms to export oriented value chains, and limited the role of states and associations. In their detailed analysis, Avendeno et al. (2006, p. 93) conclude that the "Master Plan" for food safety is “ambitious but unreachable," with its weak attention, resources, or even legal authority for SENASICA to build the institutional infrastructure for certification and training at both the level of the regulator and the firm. Hence, without integration mechanisms that focused on capacity building and promote multiplex transnational ties, the supply side of domestic institutional development in Mexico became susceptible to changes in administrations and poorly funded.

The demand side changes have largely been triggered by the aforementioned periodic health crises linked to Mexican food products and subsequent import bans by the US. The US agencies would collaborate with local SENASICA offices to establish systems of traceability and monitoring as well as initial programs to educate producers about US standards for products, GAPs, and GMPs. Such interventions by the US have gradually improved food safety standards and monitoring systems for a few export oriented firms in specific sectors, namely avocados, cantaloupe, mangos, citrus, green onions, and beef. But as much as US actions appear to mimic the EU approach to institution building, the continued emphasis on dyadic forms of and limited resources for assistance and monitoring has narrowed the participation of economic and political 
actors and limited spillovers in standards and practices from the export value chains to the domestic market.

On the one hand, the US has continued a dyadic approach to assisting Mexican authorities when crises occur. At the national level, the US and Mexican agencies have established bi-lateral working groups that regularly exchange information on standards and outbreaks on specific product groups. (Green et al. 2006) At the same time, the FDA and USDA have established new systems of certification of producers in Mexico for a few products and regions in the wake of import bans, while still maintaining extensive border checks of certified producers. (Avendano et al 2009, Alvarez 2006, Calvin 2003, Stanford 2002)

On the other hand, there is no systematic program by US to assist or demand comprehensive capacity building for either public institutions or firms in Mexico. Only in the meat and dairy products does the USDA have the authority to evaluate national programs to determine equivalence or to visit foreign countries to verify compliance with food safety procedures. In this case, there is only a ten person team conducting regular evaluations of 41 countries. While the team can make recommendations to e.g., Mexico, it has no competency to assist their counterparts in capacity building, other than refer them to USAID. In the case of pestilence problems, the USDA maintains a network of paid employees - both US and Mexican nationals - to monitor fields and certify producers for avocados, citrus and mangos, rather than help the Mexicans take this responsibility themselves. According to WTO data, from 2001 to 2009 , the US has spent only about $\$ 750,000$ on training and education programs for SPS issues in Mexico, a pittance compared even to EU support for just Romania. ${ }^{13}$

\footnotetext{
${ }^{13}$ WTO data for Trade Capacity Building for SPS Measures can be found at: http://tcbdb.wto.org/category_project.aspx?cat=33113
} 
As for non-state actors, the combination of poorly coordinated and weakly funded assistance programs have led the export sectors to be dominated by large domestic and foreign firms that already had the distribution systems and resources to organize proprietary value chains and invest in the needed capabilities, be they for improved efficiencies or quality control. Studies of products as varied as avocados, tomatoes, green onions, cantaloupes, limes, and mangos reveal that the fixed and variable costs of meeting the new standards reach into the hundreds of thousands of dollars per firm, which the producer alone must bear. (Alvarez 2006; Avendano et al 2006, 2009) Small and medium size producers cannot stay in the export market. For instance, in their 2002-03 survey of fresh vegetable producers in three of the most export oriented states, Avendano et al (2009) reveal that although over $80 \%$ of respondents are aware of the new US standards, less than half complied with them and the vast majority were not aware of the Mexican government's food safety laws or its support programs. In the case of cantaloupes, the combination of the 2001 ban by the US, the subsequent certification process, and new competition by other Latin American countries led to a $60 \%$ decrease in US market share in 3 years. Although there were over 100 firms exporting cantaloupes to the US in the 1990s, by 2007 only 13 were certified to export. (Avendano et al 2009) Although the state of Michoacan accounts for $40 \%$ of the world's avocados, only $8 \%$ of the estimated 6000 growers were export certified for the US by 2001. (Stanford 2002) These studies conclude that ability of growers to build new capabilities and develop collective non-state organizations depends largely on whether the sector/location is highly concentrated and dominated by large producers. As a result, the large majority of producers have exited the export market and turned to focusing on supplying the domestic market, where profits are lower and regulations weaker. 
The ability of producers to collectively organize and access government assistance is constrained by the legacy of fragmented industry structures and the lack of cross-border collaboration with their US counterparts. For instance, even when the US and Mexican authorities have established an organization for producer certification and monitoring, large firms tend to push their way into control. Alvarez (2006) documents that when EMEX, an organization that regulated packing sheds, provided assistance to packers, and promoted exporters, transformed itself from a state-owned to non-state association, the 20 largest exporters gained majority control by requiring that voting be proportional to the number of boxes exported. In turn, these exporters now control the rules of certification, distribution of resources, and negotiations with the USDA and the SENASICA on behalf of all mango growers and packers. At the same time, beyond getting certified to become a global supplier, producers have few avenues to develop socio-professional ties with US firms. As mentioned above, the NAFTA initiated non-profit DRC appears to lack an interest in gaining Mexican participants. In some cases, US associations have overtly blocked channels to Mexico. For instance, in the wake of the strawberry contamination in 1997, the California Strawberry Commission created a Quality Assurance Food Safety program, but refused to allow the Mexican producers to partake in the commission or program.

In sum, we find that the integration mechanisms of NAFTA have allowed Mexico to increase its sales to the US, but have not been able to induce broad based institutional upgrading - be it for regulation or firm support. There were few resources provided by NAFTA or the US government to the Mexican government and few channels of coordination and coalition building. On the demand side, despite the increased intervention of the US agencies into Mexico, their dyadic approach and the limited assistance allowed the most entrenched, powerful actors in 
Mexico to invest in new capabilities, develop international trade relations, and lobby government officials to improve their market access and regulatory needs. That is, rather than devoting economic, political and social capital toward creating institutions to help improve and implement standards, public and private actors focus discussing standards in terms of trade conflict. (Hufbauer \& Schott 2005)

\section{Conclusions}

While we do not discount domestic political-economic legacies, the stark divergence in institutional paths between East and South, beckons a closer examination of ways in which transnational regional arrangements and foreign actors shape institutional development. This paper has attempted to offer an alternative approach to development that combines recent advances in research in comparative and international political economy. We have argued that the paths of institutional development for emerging market democracies are largely functions of the TIR, in which the country is embedded. Our comparative framework suggests that as development programs, TIRs differ in the ways they translate their purpose and power into distinct sets of integration mechanisms, rather than simply their emphasis on market incentives, largess, or hierarchical conditionality. In doing so, we also aspired to introduce concepts that could be incorporated into development programs and TIRs beyond those affecting Mexico and the post-communist countries.

We argued that the post-communist countries participating in the EU Accession Process have surpassed Mexico via NAFTA largely because of the ways in which the EU has emphasized: a) the construction of institutional capacities in a variety of policy domains, instead of just policy outcomes, b) the multiplex nature of assistance and monitoring, and c) the adaptation of coordination at the supra-national level. The combination of these mechanisms has 
reshaped the supply side not only by affording governments access to diverse forms of knowledge and material resources but also by pushing them to build multi-level state capacities that can resist the pressures of powerful entrenched interests and open policymaking to weaker groups. They have reshaped the demand side by empowering a variety of state and non-state actors to participate in institutional building and recombine their resources. This was achieved not only through the vertical transfer of resources and rights but also through the concerted creation of multiple social, economic, and political linkages among domestic and foreign state and non-state actors.

The EU approach to liberalizing trade and re-embedding domestic markets in a broad transnational regulatory regime has strengthened domestic regulatory capacities and increased the opportunities for a variety of state and non-state actors at different levels of society to make legitimate demands for upgrading institutions and participate in rule enforcement. While the EU has limited capacity to monitor and enforce its regulations in dozens of regulative fields in 27 countries, multiplex assistance and monitoring facilitated transnational public and private alliances among actors from the old and new member states, including them in a decentralized system of rule enforcement, knowledge transfer, and mobilization. (Tallberg, 2000, Bruszt and Vedres, 2009) In contrast, NAFTA's focus on a narrow set of policy goals, emphasis on arm'slength incentives, and reliance on dyadic forms of assistance and monitoring tended to reinforce the relative power of entrenched elites in Mexico. The result has been the somewhat conflicting trends of weak diffusion of regulatory capacities and standards into the domestic domain and the gradual, reluctant intervention by US government agencies into Mexican institutional upgrading.

This work invites two areas of further research on externally induced institutional change in developing countries. First, it invites debate about the different types of transnational 
integration mechanisms that can shape domestic institutional development regardless of TIR or policy domain. For instance, research on regulatory institutions in countries outside of strong TIRs can help clarify the extent to which an emphasis on capacity building and the use of empowered multiplexity in assistance and monitoring can reinforce aid programs to harness the participation and experiments of a variety of state and non-state actors. Second, a clear issue is clarifying the broader political conditions that induce existing TIRs, such as NAFTA, CAFTA, or the Mercosur, to translate their purpose and power into the integration mechanisms that we outlined above. For instance, our aforementioned analysis revealed the tensions within the USDA and FDA about the need to move to a proactive, comprehensive approach to institution building in Mexico and the limitations in their competencies to do so. This would depend not only on political fights within the US but also Mexican suspicion of tying such changes to renegotiation of existing trade agreements. In turn, political analysis should focus less on conditions for a complete overhaul of NAFTA and more on the institutional experiments that are remaking transnational integration mechanisms in distinct policy domains. In contrast, the recent opening of an independent judiciary and the imminent creation of a parliament in the Mercosur offers an opportunity to analyze how the strengthening of supra-national institutions impact the domestic changes in regulatory institutions and mobilization of local stakeholder groups. 
Figure 1. The South Liberalizes Faster than the East

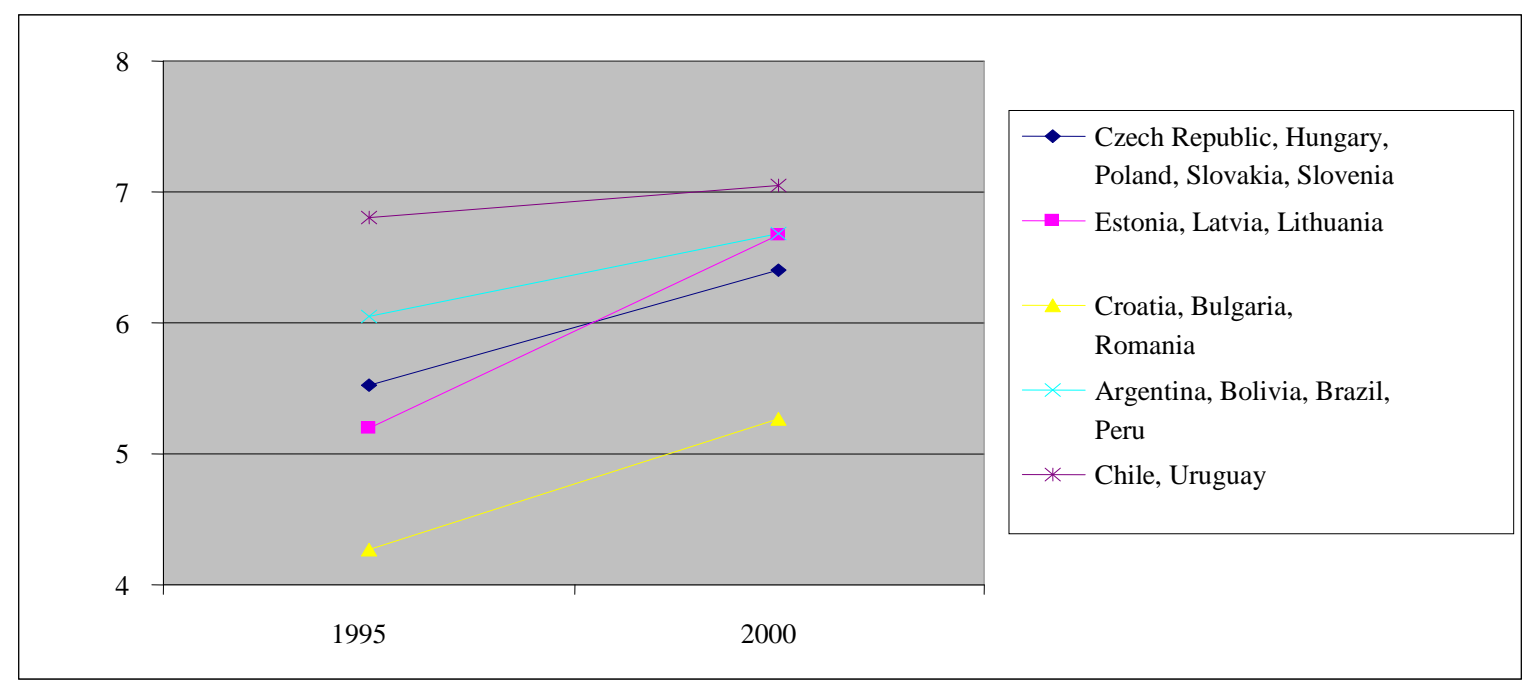

Source: Cato Economic Freedom index

Figures 2a-b. Comparisons Governance and Institutional Quality, 1996-2006 (Source: Kaufmann, Kraay and Mastruzzi (2007))

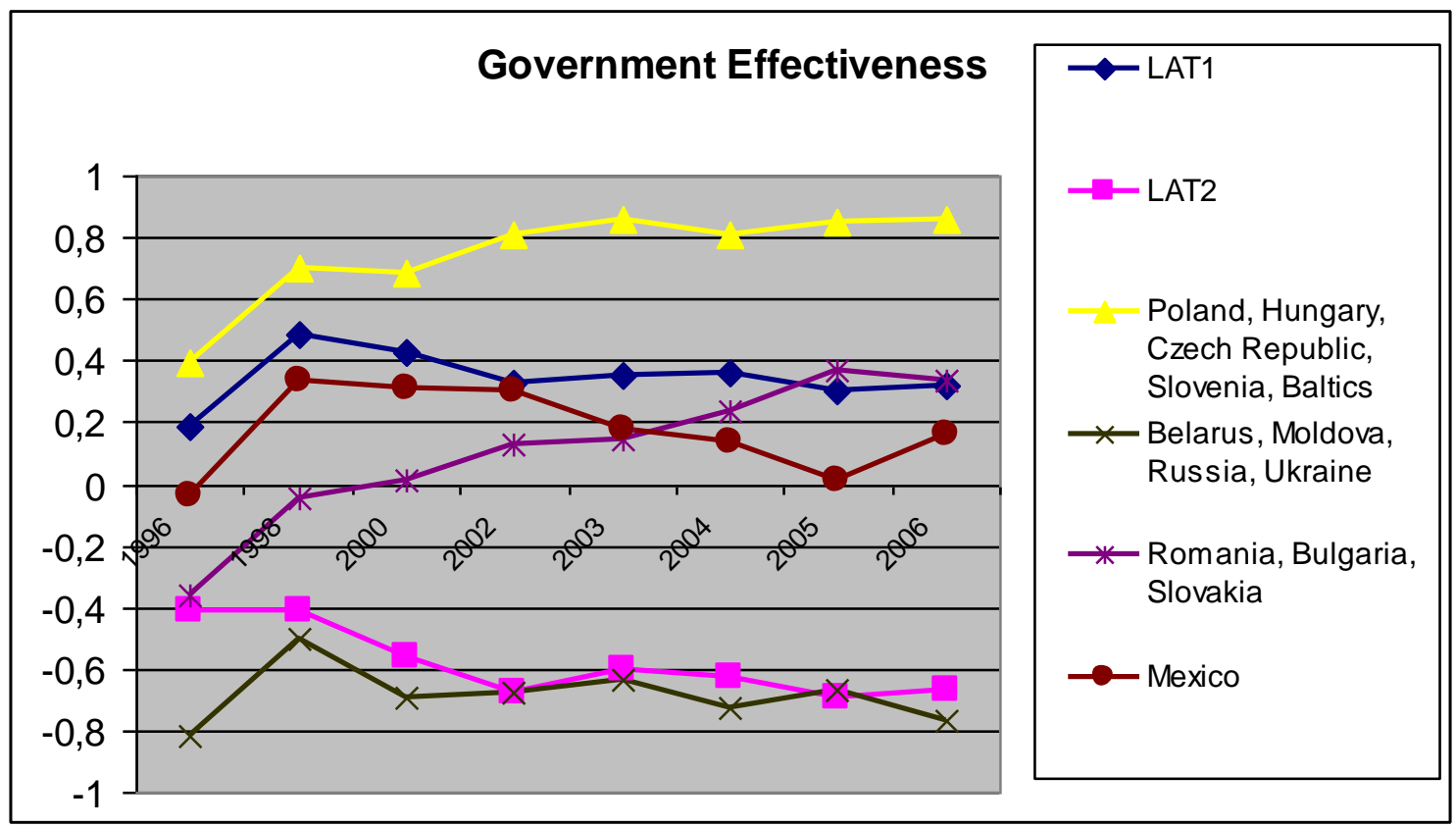

NB: LAT1 = Argentina, Brazil, Chile, México, Uruguay; LAT 2 = Bolivia, Colombia, Ecuador, Paraguay, Venezuela, Peru. 
Figure 2c.

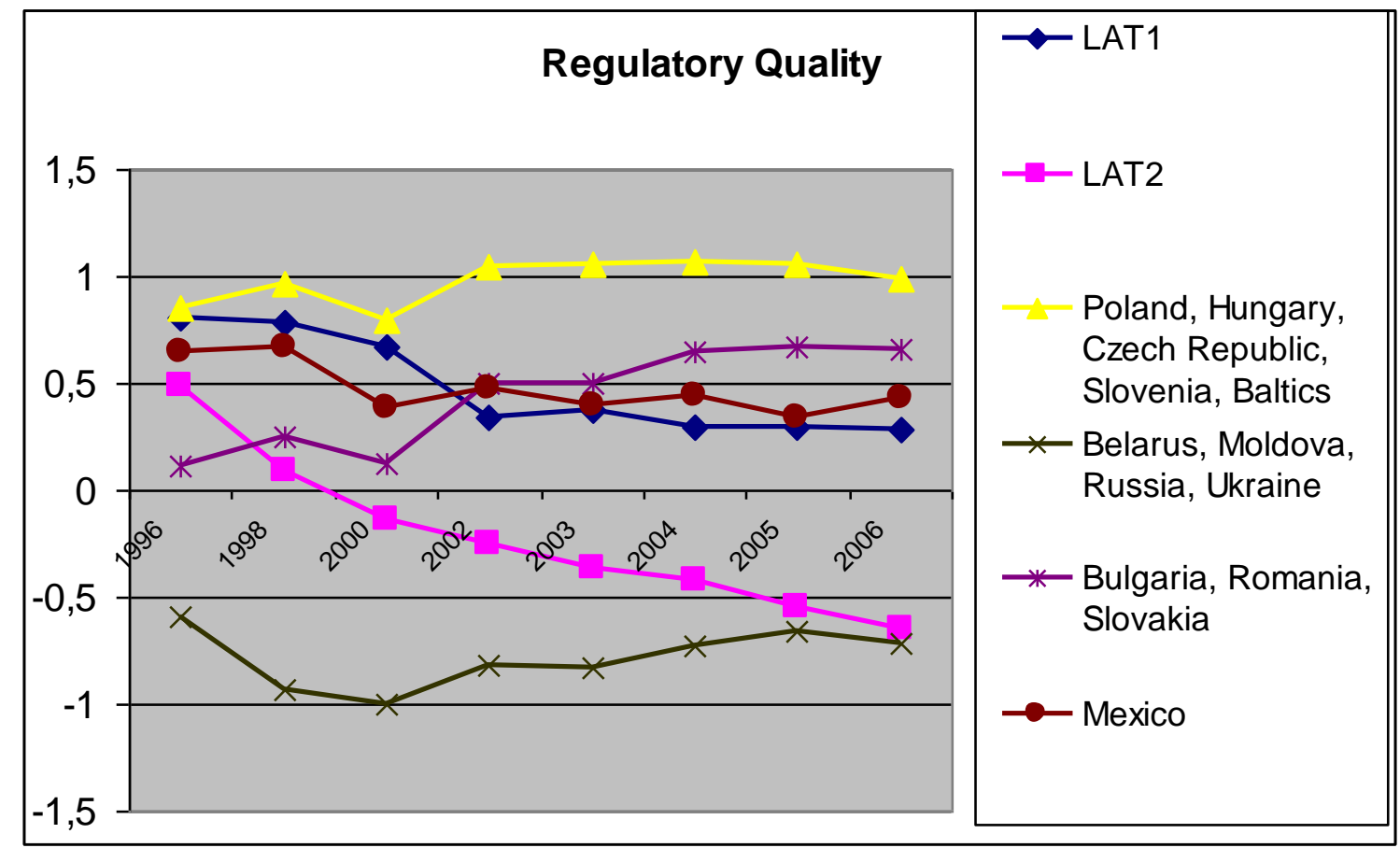

NB: LAT1 = Argentina, Brazil, Chile, México, Uruguay; LAT 2 = Bolivia, Colombia, Ecuador, Paraguay, Venezuela, Peru.

Figure 3a. Regulation Quality \& Gov't Effectiveness - Distance from Income Group Mean

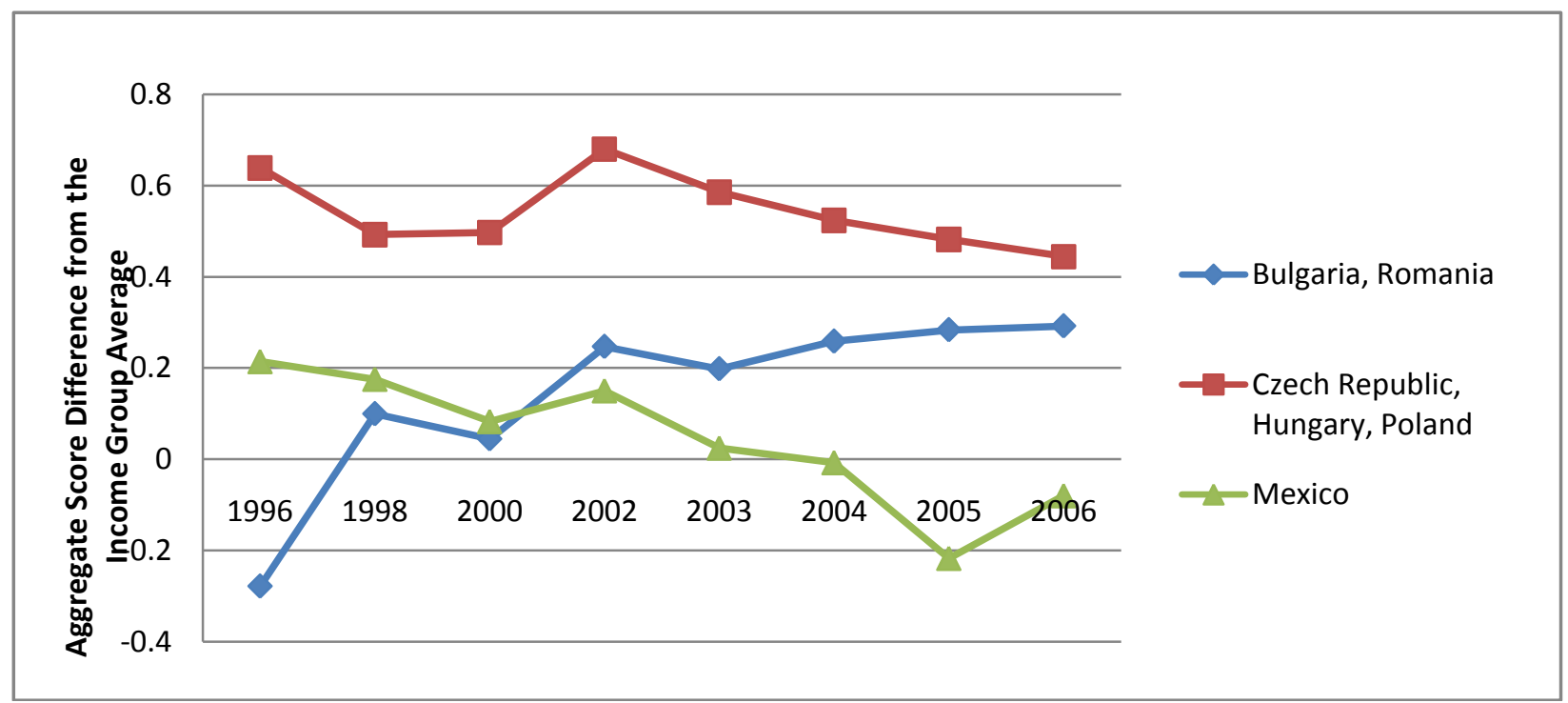

Source: Kaufmann, Kraay and Mastruzzi (2007) 
Figure 3b. Control of Corruption \& Rule of Law - Distance from Income Group Mean

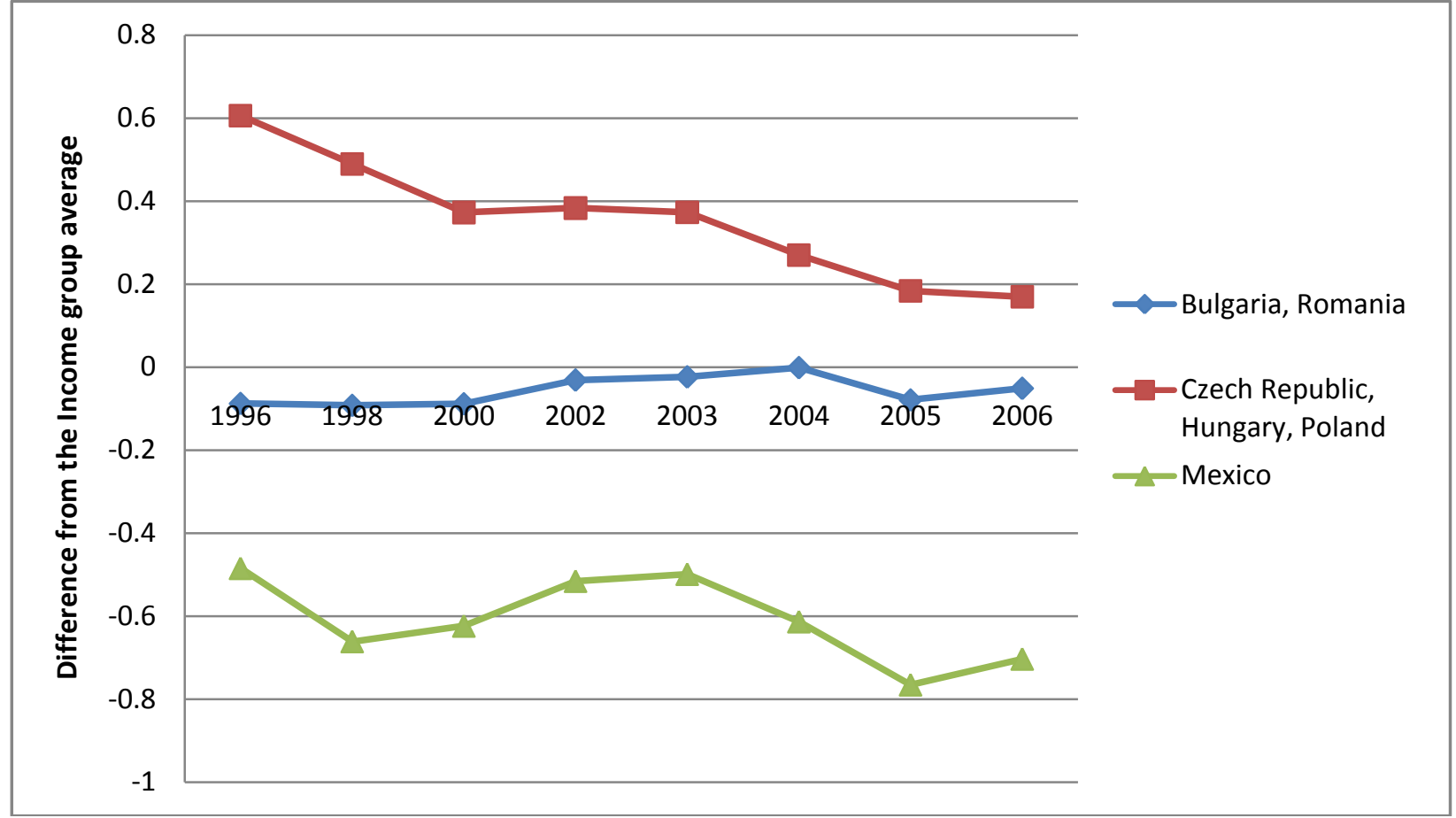

Source: Kaufmann, Kraay and Mastruzzi (2007)

Figure 4. Comparison of Labor Rights Institutions, 1995-2000

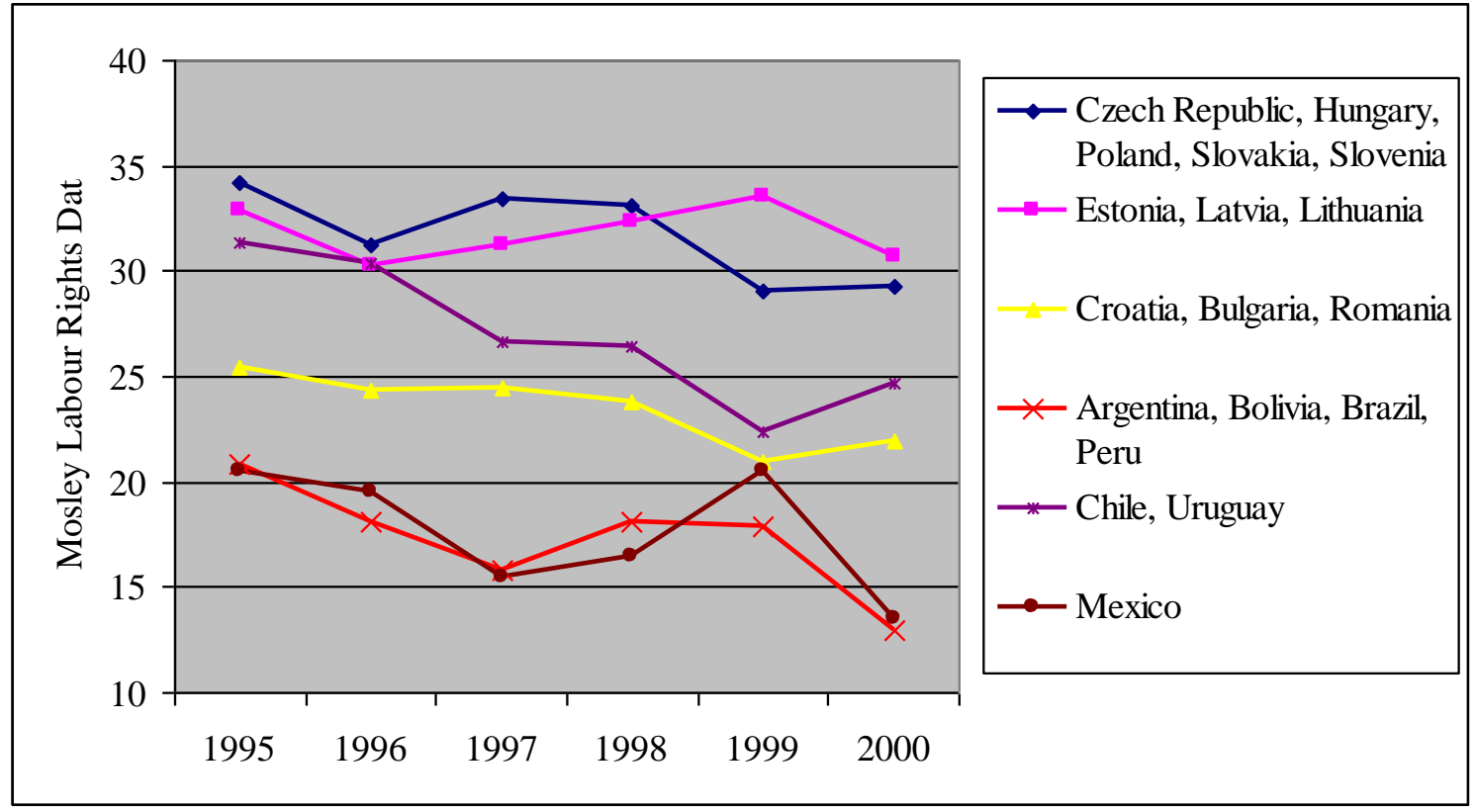

Source: Mosley \& Uno (2007) Overall points around 30 indicate the presence of public control over the rules of the game in the highly asymmetrical labor-business relations. 


\section{Bibliography}

Abdelal, R., M. Blyth \& C. Parsons, 2010, Constructing the International Political Economy. Ithaca: Cornell University Press.

Alvarez, R., 2006, "The Transnational State and Empire: U.S. Certification in the Mexican Mango and Persian Lime Industries", Human Organization, 65(1), 35-45.

Amsden, A.H., 2007, Escape from empire: the developing world's journey through heaven and hell, Cambridge, Mass: MIT Press.

Andonova, L.B., 2004, Transnational politics of the environment: the European Union and environmental policy in Central and Eastern Europe, Cambridge, Mass: MIT Press.

Ansell, C., 2000, "The Networked Polity: Regional Development in Western Europe", Governance, 13(2), 279-293.

Avendano, B., R. Rindermann, S. Lugo Morones, and A.M. Lagarda, 2006, La Inocuidad Alimentaria en México. Mexico: Universidad Autónoma de Baja California.

Avendano, B., C. Narrod, M. Tarongco, 2009, "Food Safety Requirements for Cantaloupe Exports from Mexico and their Impact on Small Farmers' Access to Export Markets," IFPRI Discussion Paper, May.

Bailey, D. and L.D. Propris, 2004, "A Bridge Too Phare? EU Pre-Accession Aid and CapacityBuilding in the Candidate Countries", Journal of Common Market Studies, 42 (1): 77-98.

Barnett, M., 2004, The Pentagon's New Map: War and Peace in the Twenty-First Century. New York: Putnam.

Bavorova, M., J. Curtiss and L. Jelinek, 2005, "Czech Agricultural Associations and the Impact of Membership on Farm Efficiency," Paper presented at the EAAE Seminar on Institutional Units in Agriculture, UK, April 9-10.

Börzel, T. and T. Risse, 2000, When Europe Hits Home: Europeanization and Domestic Change EUI Working Papers.' RSC No. 2000/56.

Bredahl, M. and E. Holleran, 1997, "Technical Regulations and Food Safety in NAFTA", Harmonization/Convergence/Compatibility in Agricultureand Agri-Food Policy: Canada, United States and Mexico, Loyns, R.M.A.and others (eds.), proceedings of the Third Agricultural and Policy Systems Information Workshop, October.

Bruszt, L., 2002a, "Making Markets and Eastern Enlargement: Diverging Convergence?", West European Politics, 25 (2): 121-140.

Bruszt, L., 2002b, "Market Making as State Making: Constitutions and Economic Development in Post-communist Eastern Europe”, Constitutional Political Economy, 13: 53-72. 
Buskova, K. and H. Pleines, 2006, "Case Study: Czech Environmental NGOs and the EU”, in Pleines Heiko (ed.) Participation of Civil Society in New Modes of Governance Part 3 Forschungstelle Osteuropa Bremen Arbeitspapiere and Materialen.

Caballero, R. and R. Dornbusch, 2002, “Argentina Cannot Be Trusted," Financial Times, March 8.

Calvin, L., 2003, "Produce, Food Safety, and International Trade: Response to U.S. Foodborne Illness Outbreaks Associated with Imported Produce," in J. Buzby, (Ed.) International trade and food safety: Economic theory and case studies. Washington DC: United States Department of Agriculture, Agricultural Economic Report 828.

Cohen, J. and C.F. Sabel, 2003, "Sovereignty and Solidarity: EU and US" in Zeitlin, J. and Trubek, D. (Eds) From governing work and welfare in a new economy: European and American experiments. Oxford: Oxford University Press

Collier, R.B. and S.P. Handlin, 2005, "Shifting Interest Regimes of the Working Classes in Latin America" Working Paper Institute of Industrial Relations, University of California, Berkeley.

Djelic, M.-L. and K. Sahlin-Andersson (Eds.), 2006, Transnational governance: institutional dynamics of regulation, Cambridge: Cambridge University Press.

Dolezal, P and B. Janackova, 2005, "Review of Food Law and Some Experiences Related to the Accession of the Czech Republic to the EU," Institute for European Policy Working Paper.

Duina, F., 2007, The social construction of free trade: The European Union, NAFTA, and Mercosur. Princeton, NJ: Princeton University Press.

Easterly, W.R., 2006, The white man's burden: why the West's efforts to aid the rest have done so much ill and so little good, New York: Penguin Press.

Ekiert, G., and S.E. Hanson (Eds), 2003, Capitalism and democracy in Central and Eastern Europe. Assessing the legacy of communist rule. Cambridge: Cambridge University Press.

Epstein, R., 2008, In Pursuit of Liberalism: International Institutions in Postcommunist Europe. Baltimore: Johns Hopkins University Press.

European Commission DG-General Enlargement, 2007, "Supporting Enlargement - What Does Evaluation Show? Ex post evaluation of Phare support allocated between 1999-2001, with a brief review of post-2001 allocations July 2007" http://ec.europa.eu/enlargement/pdf/ financial_assistance/phare/evaluation/consolidated_summary_report_phare_ex_post_eval.pdf

European Commission DG SANCO FVO, 2009, "Final Country Profile of Romania on Food and Feed Safety, Animal Health, Animal Welfare, and Plant Health," DC(SANCO)/8113/2009.

Evans, P., 2004, 'Development as Institutional Change: The Pitfalls of Institutional 
Monocropping and the Potentials for Deliberations", Studies in Comparative International Development, 38 (4): 30-52.

Gallagher, K.P., 2007, The Enclave Economy, Cambridge: MIT Press.

Garcia-Martinez, M., N. Poole, C. Skinner, C. Illes, and J. Lehota, 2006, "Food Safety Performance in European Union Accession Countries: Benchmarking the Fresh Produce Import Sector in Hungary", Winter 2006, 22 (1): 69-89.

Gatzweiler, F.-W., R. Judis, and K. Hagedorn, (Eds.), 2002, Sustainable Agriculture in Central and Eastern European Countries: The Environmental Effects of Transition and Needs for Change. Institutional Change in Agriculture and Natural Resources, vol. 10. Aachen, Germany: Shaker.

Green, T., L. Hanson, L. Lee, H. Fanghanel, \& S. Zahniser, 2005, "North American Approaches to Regulatory Coordination," in Huff et al, eds., Agrifood Regulatory and Policy Integration Under Stress. NAAMIC.

Grugel, J., 2004, "New Regionalism and Modes of Governance- Comparing US and EU Strategies in Latin America", European Journal of International Relations, 10 (4): 603-626.

Hall, P.A., and D. Soskice (Eds), 2001, Varieties of capitalism, The institutional foundations of comparative advantage. Oxford: Oxford University Press.

Heil, P., 2000, PHARE in Hungary: The anatomy of a pre-accession aid programme, 1990-1999. Unpublished PhD Dissertation, Budapest. University of Economics.

Hellman, J., 1998, "Winners Take All: The Politics of Partial Reform in Postcommunist Transitions". World Politics, 50(2), January, 203-234.

Hufbauer, G.C. and J.J. Schott, 2005, NAFTA Revisited: Achievements and Challenges, Washington DC: Peterson Institute.

Hughes, J., G. Sasse, and C. Gordon, 2004, Europeanization and regionalization in the EU's enlargement to Central and Eastern Europe: the myth of conditionality. Basingstoke: Palgrave Macmillan.

Jacoby, W., 2000, Imitation and politics: redesigning Germany, Ithaca, NY: Cornell University Press.

Jacoby, W., 2004, The enlargement of the European Union and NATO: ordering from the menu in Central Europe, Cambridge; New York: Cambridge University Press.

Jordana, J. and D. Levi-Faur, 2005, "The Diffusion of Regulatory Capitalism in Latin America: Sectoral and National Channels in the Making of a New Order", The Annals of the American Academy, 598: 102-124. 
Karl, T., 2008, “The Vicious Cycle of Inequality in Latin America”, in Susan Eva Eckstein and Timothy P. Wickham-Crowley (eds.), The politics of injustice in Latin America, Berkeley: University of California Press.

Kaufmann, D., A. Kraay, and M. Mastruzzi, 2007, “Governance Matters VI: Governance Indicators for 1996-2006” The World Bank Policy Research Working Paper No. 4280.

Kelemen, D., and A. Tarrant, 2007, “The Politics of Eurocracy: Designing EU regulatory agencies and networks" Paper presented at the European Union Studies Association Convention, Montréal, Canada, 18-20 May 2007

Lederman, D., W.F. Maloney, and L.L. Servén, 2005, Lessons from NAFTA for Latin America and the Caribbean, Washington, DC: World Bank; Stanford: Stanford University Press.

Levi-Faur, D., 2006, "Regulatory Capitalism: The Dynamics of Change beyond Telecoms and Electricity", Governance: An International Journal of Policy, Administration, and Institutions, 19 (3): 497-525.

Levitsky, S. \& L. Way, 2006, "Linkage versus Leverage: Rethinking the International Dimension of Regime Change," Comparative Politics 38(4): 379-400.

Locke, R. and M. Romis, 2010, "The promise and perils of private voluntary regulation: Labor standards and work organization in two Mexican garment factories," Review of International Political Economy, 17(1): 47-74.

Mann, M., 1984, "The Autonomous Power of the State: Its Origins, Mechanisms, and Results", Archives européenes de sociologie, 25: 185-213.

Mansfield, E.D. and H.V. Milner (Eds.), 1997, The political economy of regionalism, New York: Columbia University Press.

Mayhew, A., 1998, Recreating Europe: the European Union's policy towards Central and Eastern Europe. Cambridge: Cambridge University Press.

McDermott, G.A., 2002, Embedded politics: industrial networks and institutional change in postcommunism. Ann Arbor, MI: University of Michigan Press.

McDermott, G.A., 2007a, "The Politics of Institutional Renovation and Economic Upgrading: Recombining the Vines that Bind in Argentina," Politics and Society, 35(1), 103-143.

McDermott, G.A., 2007b, "Politics, Power, and Institution Building: Bank Crises and Supervision in East Central Europe," Review of International Political Economy, 14(2): 220-250.

Mishev, P. and E. Valcheva, 2005, "Origin-labeled Products - Food Quality and Food Safety in Bulgaria”, Society and Economy, 27 (3): 299-308. 
Mosley, L. and S. Uno, 2007, "Racing to the Bottom or Climbing to the Top? Economic Globalization and Collective Labor Rights”, Comparative Political Studies, 40 (8): 923-948.

Moss, D., 2002, When all else fails: government as the ultimate risk manager. Cambridge: Harvard University Press.

National Research Council, 2000, Incorporating Science, Economics, and Sociology in Developing Sanitary and Phytosanitary Standards in International Trade: Proceedings of a Conference. Washington DC: National Academy Press.

Orenstein, M., S. Bloom, and N. Lindstrom (Eds), 2008, Transnational actors in Central and East European transitions. Pittsburgh: University of Pittsburgh Press.

Padgett, J. \& C. Ansell, 1993, "Robust action and the rise of the Medici, 1400-1434," American Journal of Sociology, 98(6): 1259-1320.

Pastor, R.A., 2001, Toward a North American community: lessons from the Old World for the New. Washington, DC: Peterson Institute.

Pevehouse. J.C., 2005, Democracy from above : regional organizations and democratization. New York: Cambridge University Press.

Piore, M., and C. Sabel, 1984, The second industrial divide. New York: Basic Books.

Przeworski, A., 1991, “The 'East' Becomes 'South'? The 'Autumn of the People' and the Future of Eastern Europe, PS: Poliitcal Science and Politics, 24(1): 20-24.

Rodrik, D. 2004 "Industrial policy for the twenty-First century," Working paper prepared for UNIDO.

Ruggie, J., 1982, "International Regimes, Transactions, and Change: Embedded Liberalism in the Postwar Economic Order," International Organization, 36(2): 379-415.

Sabel, C., 1994, "Learning by Monitoring: The Institutions of Economic Development." in N.

Smelser and R. Swedberg, (Eds), Handbook of economic sociology. Princeton: Princeton University Press and Russell Sage Foundation, pp. 137-165.

Sabel, C.F. and J. Zeitlin, 2007, "Learning from Difference: The New Architecture of Experimentalist Governance in the European Union”, Working Paper No. 2007-020, La Follette School, Forthcoming as a European Governance (EUROGOV) Working Paper, Revised May 7, 2007.

Schimmelfennig, Frank, and Ulrich Sedelmeier (Eds), 2005, The Europeanization of Central and Eastern Europe, Ithaca, NY: Cornell University Press.

Schimmelfennig, F. and U. Sedelmeier, 2002, “Theorizing EU Enlargement: Research Focus, 
Hypothesis and the State of Research", Journal of European Public Policy, 9: 500-528.

Schneider, B.R., 2004, "Varieties of Semi-Articulated Capitalism in Latin America". Paper presented at the Annual Meeting of the American Political Science Association, Chicago, September $2-5$.

Sedelmeier, U., 2006, "Europeanisation in New Member and Candidate States", Living Reviews in European Governance, 1 (3), http://www.livingreviews.org/lreg-2006-3, cited on 12.10.2007.

Stanford, L., 2002, “Constructing 'Quality': The Political Economy of Standards in Mexico's Avocado Industry", Agriculture and Human Values, 19: 293-310.

Stark, D. and L. Bruszt, 1998, Postsocialist pathways: transforming politics and property in East Central Europe, New York and Cambridge: Cambridge University Press.

Streeck, W. and P.C. Schmitter, 1985, "Community, Market, State - and Associations?: The Prospective Contribution of Interest Governance to Social Order", European Sociological Review, 1 (2): 214-243, September 1985.

Studer, I. and C. Wise (Eds.), 2007, Requiem or revival?: the promise of North American integration, Washington, DC: Brookings Institution Press.

Sunstein, C., 1990, After the rights revolution. Cambridge, Boston, MA: Harvard University Press.

Tendler, J., 1997, Good government in the tropics. Baltimore, MD: Johns Hopkins University Press.

Vachudova, M.A., 2005, Europe undivided: democracy, leverage, and integration after communism. New York: Oxford University Press.

Vachudova, M.A., 2008, "The European Union: The Causal Behemouth of Transnational Influence on Postcommunist Politics," in Orenstein et al eds, Transnational actors in Central and East European transitions. Pittsburgh: University of Pittsburgh Press.

Warleigh-Lack, A., 2006, "Towards a Conceptual Framework for Regionalisation: Bridging 'new regionalism' and 'integration theory," Review of International Political Economy, 13(5): 750-771.

World Bank, 2005, "Romanian Food and Agriculture from a European Perspective," ECSSD Working Paper No. 39.

Yakova, I., 2005/2006, “Czech Republic, 'Europe' and its farmers: How is Agricultural Interest Intermediation Affected by Accession to the EU", European Political Economy Review, 3 (2): $112-142$. 